\title{
Enhanced Fishing Rights under the United Nations Convention on the Law of the Sea, 1982: The Challenges Confronting Developing Countries
}

\author{
Vincent Iwunze ${ }^{*}$ \\ https://doi.org/10.21827/GroJIL.7.2.145-163
}

\section{Keywords \\ FISHING; SEA; CONVENTION; CHALLENGES; DEVELOPING COUNTRIES}

\begin{abstract}
Prior to the adoption of the United Nations Convention on the Law of the Sea (UNCLOS) in 1982, fisheries played only a minor role in the economies of most developing countries. Fisheries resources in waters adjacent to the coasts of many developing countries were largely exploited by fishers from the developed nations of the world who had the requisite technologies for deep-sea fishing. These technologies were lacking in developing countries, resulting in sub-optimal marine fishing. However, the adoption of UNLCOS in 1982 introduced novel principles for the governance of marine fisheries. It was widely believed that these innovations would enhance and stabilise fishing rights, redistribute income from marine fisheries to the advantage of developing countries and reduce the incidents of international conflicts concerning fishing rights. This paper critically examines the various ways through which UNCLOS has enhanced and stabilised fishing rights for the benefit of all States, especially developing countries. It asserts that due to various challenges that continue to confront developing countries with respect to the utilisation of marine fisheries, the benefits anticipated to accrue to them under UNCLOS have remained elusive throughout the thirty years since the Convention was adopted. The paper makes suggestions for the improvement of fisheries resources utilisation among developing countries.
\end{abstract}

\section{Introduction}

The importance of the sea to mankind cannot be over-emphasised. Comprising three-quarters of the surface of the Earth, ${ }^{1}$ it has, through the ages, been a means of trade and transportation. In the modern age, the sea has become even more beneficial to mankind as its resources are progressively revealed by science and technology. While deep-sea oil exploration has provided

* Vincent Iwunze, Esq, BL, LLM, PhD, Lecturer in the Faculty of Law, University of Uyo, Uyo, Nigeria. He may be reached at paramounts@outlook.com.

1 EE Essien, Essays in International Law of the Sea (Golden Educational Publishers 1994) 108; E Holmina, 'Common Heritage of Mankind in the Law of the Sea' (2005) 1 Acta Societas Tis Martensis 187. 
a significant source of the energy required to meet the needs of the world, ${ }^{2}$ and the seas have been found to hold enormous quantities of minerals, ${ }^{3}$ there are more than a few countries whose foreign exchange earnings are connected substantially, if not totally, to deep-sea fishing. ${ }^{4}$

As technology developed, the exploitation of the fisheries resources of the sea also developed. Technology took fishing from the immediate maritime belts of coastal States to the deep sea, following the manufacture of distance-fishing vessels, the introduction of freezing technology, the development of railway networks, sonar, Global Positioning System (GPS) and the discovery of canning methods for the preservation of fish. ${ }^{5}$

Given the continuously increasing capacities of States to embark on deep-sea fishing, and considering the foreign exchange earning profiles of fishery resources for the traditional distance-fishing countries, ${ }^{6}$ it would be natural to expect that States would exhibit tendencies of territoriality over the sea and try to appropriate parts of it for exclusive fishing rights. They did. History is, therefore, strewn with cases of disagreements over fishing rights between nations, a factor that may have prompted Professor Essien to assert, rather figuratively, that 'ever since the Biblical Jonah and the whale, nations have been arguing over fishing rights.' 7

However, since the capacities for deep-sea fishing have been and remain disparate between nations, some nations have benefited more from fisheries resources than others. While the developed nations have, over the years, exploited different parts of the seas with their distance-fishing fleets and thereby earned enormous resources, the developing ones, which lack the technology and technical know-how to do so, watched helplessly from the sidelines. It was, indeed, a case of developed countries distance-fishing for their own benefit in the backyards of developing countries, depleting the fisheries resources of the coastal waters of these developing nations. The consequence of this unhealthy state of affairs was a rivalry between the developed nations which, in furtherance of their economic interests, wanted a narrower territorial sea for coastal nations, and the developing nations which, for the purpose of preserving the fisheries and other resources of their coastal waters, preferred a wider territorial sea.

This state of affairs also left the issue of States' fisheries jurisdiction in a state of kaleidoscopic flux since States arbitrarily declared as their own and appropriated variegated

2 Offshore oil production is about 27 million barrels of oil per day (about $30 \%$ of world oil production per day) while offshore gas production accounts for approximately half of the world's total gas production. See US Energy Information Administration, 'Offshore Production Nearly 30\% of Global Crude Oil Output in 2015' (2016) <eia.gov/todayinenergy/detail.php?id=28492> accessed 30 November 2019.

3 International Seabed Authority, 'Deep Seabed Mineral Resources' <isa.org.jm/mineral-resources/55> accessed 20 October 2019.

4 FAO, 'Information on Fisheries Management in the Republic of Iceland' $<\backslash$ fao.org/fi/olfsite/FCP/en/ISL/body.htm> accessed 29 October 2019; Z Hongzhou, 'China's Fishing Industry: Current Status, Government Policies and Future Prospects' (China as a Maritime Power Conference, Arlington, 28-29 July 2015) 1-2.

5 Jean-Paul Troadec, 'Harvesting the Seas' in Patrick Safran (ed), Fisheries and Aquaculture - Volume I(EOLSS Publications 2009); S Cullis-Suzuki and D Pauly, 'Failing the High Seas: A Global Evaluation of Regional Fisheries Management Organizations' (2010) 34 Marine Policy 1036. Iceland, Norway and Japan are examples.

7 Essien (n 1) 12. 


\section{Enhanced Fishing Rights under the United Nations Convention on the Law of the Sea, 1982: The Challenges Confronting Developing Countries 147}

breadths of fishing zones. It was not until 1982, through the instrumentality of UNCLOS, ${ }^{8}$ that certainty and innovatory changes were infused into the regime of fisheries jurisdiction in the international law of the sea.

This paper examines the various ways in which fishing rights have been enhanced and stabilised among States under UNCLOS and the challenges confronting developing countries in the maximisation of Convention benefits in this regard. The paper proceeds in five major parts. Part 1 introduces the subject matter, while Part 2 reviews the law and practice relating to fisheries jurisdiction and fishing rights among States in the period before UNCLOS. Part 3 examines the position of the law under UNCLOS, while in Part 4, the paper critically examines the challenges confronting developing countries in the maximisation of the economic prospects offered by enhanced marine fishing rights under UNCLOS. In Part 5, the author submits suggestions for improving the economic benefits accruable to developing countries from their marine fisheries under UNCLOS.

\section{Law and Practice Prior to UNCLOS (1982)}

As previously noted, ${ }^{9}$ prior to the adoption of UNCLOS the issue of fishing rights and fisheries jurisdiction was in a state of flux, as States unilaterally determined and declared the extent of their fisheries jurisdiction. There were no commonly accepted yardsticks for such determinations. The developed, distance-fishing nations with sophisticated fishing fleets and equipment exploited the fisheries resources off the coasts of the less developed nations, unhindered. To prevent this, the developing coastal nations declared territorial seas wider than the customarily accepted three nautical miles. ${ }^{10}$

The problem of fishing rights was therefore one of the factors that prompted the International Law Commission (ILC) to prepare a set of rules of international law that would govern the use of the seas by States. In 1956, the ILC adopted its Report on the Law of the Sea at its Eighth Session. ${ }^{11}$ It was based upon the Report that the General Assembly of the United Nations (UN) convened at the First UN Conference on the Law of the Sea. ${ }^{12}$ The Conference, held in Geneva from 24 February to 29 April 1958, produced four separate conventions. ${ }^{13}$ The fourth of the four conventions was the Convention on Fishing and Conservation of Living Resources of the High Seas. ${ }^{14}$ This Convention focused on fishing and

8 The Convention was the outcome of the third UN Conference on the Law of the Sea convened in 1973 pursuant to General Assembly Resolution 3067 (XXVIII). The Convention was signed on 10 December 1982 at Montego Bay, Jamaica and adopted by 130 votes to four with 17 abstentions; United Nations Convention on the Law of the Sea (UNCLOS) (adopted 10 December 1982, entered into force 16 November 1994) 1833 UNTS 3, 1834 UNTS 3, 1835 UNTS 3.

9 See Introduction.

10 Essien (n 1) 6-7.

11 International Law Commission, 'Report of the International Law Commission on the Work of its Eighth Session' (4 July 1956) UN Doc A/CN.4/104.

12 Essien (n 1) 12.

13 Convention on the Territorial Sea and the Contiguous Zone (adopted 29 April 1958, entered into force 22 November 1964) 516 UNTS 205; Convention on the High Seas (adopted 29 April 1958, entered into force 30 September 1962) 450 UNTS 11; Convention on Fishing and Conservation of Living Resources of the High Seas (adopted 29 April 1958, entered into force 20 March 1966) 559 UNTS 285; Convention on the Continental Shelf (adopted 29 April 1958, entered into force 10 June 1964) 499 UNTS 311.

14 The Convention entered into force in 1966. See Convention on Fishing and Conservation of Living Resources of the High Seas (n 13). 
the conservation of fisheries and required coastal States to introduce conservation measures in areas of the high seas adjacent to their territorial seas. ${ }^{15}$ The Convention, however, did not grant exclusive fishing rights to coastal States. Aside from this, the critical issue of fishing zones, which would have introduced some semblance of limits to the exploitation of fisheries resources in the coastal waters of the developing nations, was also left unsettled under the Geneva Convention on the Territorial Sea. ${ }^{16}$

Much like the 1958 UN Conference on the Law of the Sea (UNCLOS I), the Second UN Conference on the Law of the Sea (UNCLOS II) failed to reach an agreement on the issue of the limits of the territorial sea. The question of fishery zones was thus not resolved by participating States. From 1958, the majority view was that 'in the absence of agreement to the contrary, fishing beyond the limit of a lawful territorial sea was open to all States in accordance with "freedom of fishing" on the high seas. ${ }^{17}$ Various States therefore unilaterally extended their territorial seas, while others did so through bilateral and multilateral agreements. Iceland, for example, unilaterally declared a twelve-mile exclusive fishing zone, which was recognised in the Fisheries Jurisdiction cases. ${ }^{18}$ In fact, a survey conducted by the Food and Agricultural Organisation (FAO) in 1967 showed that 33 states, including the UK, unilaterally declared exclusive fishing zones, mostly for twelve nautical miles. ${ }^{19}$

On 17 November 1960, Britain and Norway signed an agreement which would allow them, inter alia, to claim exclusive fishing rights in a fishing zone between six and twelve miles off their coasts, provided that States whose vessels had been fishing in the outer six miles of the fishing zone for the five years immediately preceding 1 January 1958 would continue to do so for a period of ten years from 31 October 1960. ${ }^{20}$ Based on this agreement, Norway extended its fishing zone from four miles to six miles on 1 April 1961, and in September of the same year further extended it to twelve miles, allowing, however, British vessels to fish in the outer six miles until 31 October 1970. A similar agreement was signed between Britain and Iceland under which Britain recognised Iceland's twelve-mile exclusive fishing zone subject to the right of British vessels to fish in the outer six miles until 11 March 1964. In 1962, a similar agreement was also concluded between Norway and the former Soviet Union. ${ }^{21}$

Since a trend appeared to have emerged among the traditional European fishing States through those agreements, European nations adopted the European Fisheries Convention in $1964,{ }^{22}$ which included the arrangements in the 1961 Anglo-Norwegian agreement and others that followed it. This Convention recognised the right of States Parties to fish in the outer six

15 UNCLOS (n 8) arts 1-4.

16 Malcolm Shaw, International Law (5th edn, Cambridge University Press 2003) 157; David Harris, Cases and Materials on International Law (6th edn, Sweet \& Maxwell 2004) 467.

17 Harris (n 16).

18 Fisheries Jurisdiction Case (UK v Iceland) (1974) ICJ Rep 1974 3; Fisheries Jurisdiction Case (FRG v Iceland) (1973) ICJ Rep 1973 175; Iceland's claim of a 50-mile exclusive fishing zone was held to be illegal.

19 Food and Agricultural Organisation (FAO), 'Limits and Status of the Territorial Sea, Exclusive Economic Zone, Fisheries Conservation Zones and the Continental Shelf' (1971) 10(6) International Legal Materials 1255.

20 The agreement incorporated the provision of a United States/Canadian proposal at the second 1960 UN Conference on the Law of the Sea. The Conference did not adopt the proposal as it failed by one vote.

21 Essien (n 1) 14.

22 European Fisheries Convention (adopted 9 March 1964, entered into force 15 March 1966) 581 UNTS 57. 


\section{Enhanced Fishing Rights under the United Nations Convention on the Law of the Sea, 1982: The Challenges Confronting Developing Countries 149}

miles of the twelve-mile fishing zones of other State Parties if such States Parties had been fishing in that zone between 1 January 1953 and 1 December 1962. ${ }^{23}$

In the Americas, Canada passed the Territorial Sea and Fishing Zone Act of 1964. Like the European Fisheries Convention, Canada asserted a twelve-mile fishing zone allowing, however, limited fishing rights to the US, France, UK, Spain, Portugal, Italy, Norway and Denmark in certain parts of the coast of Canada. ${ }^{24}$ The US followed suit in 1966 by claiming exclusive fishing rights in a nine-mile zone, additional to its original three-mile territorial sea. ${ }^{25}$

It is worth noting that, despite the agreements between these European States, and notwithstanding the European Fisheries Convention of 1964, conflicts over fishing rights could still not be kept at bay among European coastal States. Iceland, for example, whose chief foreign exchange earner was fishery resources, unilaterally declared a 50-mile fishing zone and excluded other States from fishing within that limit. This particular declaration was, however, declared illegal by the International Court of Justice (ICJ) in the Fisheries Jurisdiction cases. ${ }^{26}$

Among the developing States, the thrust of legislation and policy was for extended territorial seas for security, political and economic considerations. With the insistence of the developed coastal States on having exclusive fishing rights over fishing zones declared by and for themselves, and the unrelenting inclination of the developing ones, for various reasons, ${ }^{27}$ to have a wider breadth of territorial sea, a universal, comprehensive regime for marine fisheries governance became a desideratum. It was for this reason that a major part of the negotiations between the developed and developing countries at the Third UN Conference on the Law of the Sea (UNCLOS III) ${ }^{28}$ was dedicated to the exploitation, management and conservation of marine fisheries.

\section{The Position under UNCLOS}

UNCLOS, in several ways, introduced innovations in the law of the sea aimed at ensuring certainty in the rights of States to use the sea and exploit the resources therein. As previously noted, prior to 1982, there was no universally accepted limit of the territorial sea and fishing zone of coastal States. UNCLOS succeeded in establishing a twelve-mile territorial sea measured from the baselines of coastal States. ${ }^{29}$ This put to rest the uncertainties that characterised the unilateral and arbitrary declarations of preposterous breadths of territorial seas and fishing zones by coastal States.

The greatest developments under UNCLOS, through which fishing rights have been enhanced and stabilised, are to be found in the introduction of the novel Exclusive Economic

Essien (n 1) 14.

24 ibid 16.

25 ibid.

26 Fisheries Jurisdiction Cases (n 18).

27 Essien is of the view that, in the case of Nigeria, both fishing interests and the desire to bring more of the oil deposits of the coast within the country actuated the extension of the territorial sea; see Essien (n 1) 17.

28 The Conference at which UNCLOS was adopted; see UNCLOS (n 8); Shaw (n 16) 560-561.

29 UNCLOS (n 8) art 3. 
Zone (EEZ); ${ }^{30}$ the concept of Allowable Catch; ${ }^{31}$ management of migratory/straddling fish species $^{32}$ and provisions on the protection and preservation of the marine environment. ${ }^{33}$

\subsection{The Exclusive Economic Zone}

A major objective of the developing coastal States that participated in UNCLOS III was to prevent the distant-water fishing vessels of the technologically advanced States from unrestricted fishing in waters adjacent to the territorial seas of developing countries. As developing countries lacked the technology for deep-sea fishing, the developed, technologically advanced countries with the requisite capabilities harvested fish in that part of the seas without restriction prior to UNCLOS. However, aware of the enormity of fisheries resources in this area of the sea and realising the earning potential of their rich sea fisheries, the developing coastal States aspired to have and exercise exclusive fishing rights in those waters adjacent to their territorial seas.

At UNCLOS III, the desire of the developing countries for exclusive fishing rights in waters adjacent to their coasts was realized through the concept of the EEZ. Under UNCLOS, a coastal State is entitled to establish a 200-mile EEZ measured from the baseline. ${ }^{34}$ In Article 56 , the Convention vests on coastal States sovereign rights for the purpose of exploring and exploiting, conserving and managing the natural resources, whether living or non-living, of the waters superjacent to the seabed and of the seabed and its subsoil. These are the same rights claimed by third world countries through their agitation for exclusive resource control in that zone of the sea.

The EEZ is a resource-oriented concept and was believed by developing countries to hold the possibilities of economic prosperity, as it would allow them control of the resources of the waters adjacent to their coasts, particularly fish stocks. While coastal States are to exercise sovereign rights in the EEZ, all other States, whether coastal or landlocked, are to enjoy the freedoms of navigation and over-flight and of the laying of submarine cables and pipelines. ${ }^{35}$

The extent to which the EEZ-related provisions of UNCLOS have been beneficial to coastal States is ascertainable from the huge fisheries earnings from that sea zone for the traditional fishing nations of the world such as Iceland ${ }^{36}$ and Norway. ${ }^{37}$ On the part of the developing nations, it has drastically reduced the incidences of over-fishing and fish stock depletion in their waters by the developed, distance-fishing nations. It has also offered opportunities for the redistribution of fisheries resources and a new international economic

UNCLOS (n 8) art 61(1).

UNCLOS (n 8) art 64.

See UNCLOS (n 8) Part XII.

UNCLOS (n 8) art 57.

UNCLOS (n 8) art 58(1).

$75 \%$ of Iceland's export comprises fish products. Its annual fish harvest in recent years has fluctuated by around 1.7 million tonnes, with a landed value of USD 800 million; see Birgir Runolfsson, 'ITSQs in Icelandic Fisheries: A Rights Based Approach to Fisheries Management' (presented at workshop on The Definition and Allocation of Use Rights in European Fisheries, Brest, May 5-7 1999) <notendur.hi.is/bthru/brest.pdf> accessed 29 November 2019.

37 In 2013 alone, Norwegian vessels delivered 2.1 million tonnes of fish, crustaceans and molluscs with a landed value of NOK 12.5 billion. This was still three percent less than catches and earnings for 2012. See Statistics Norway, 'Fisheries, 2013, Preliminary Figures' (2013) <ssb.no/en/fiskeri> accessed 29 November 2019. 


\section{Enhanced Fishing Rights under the United Nations Convention on the Law of the Sea, 1982: The Challenges Confronting Developing Countries 151}

order. ${ }^{38}$ Following the adoption of UNCLOS, between 1982 and 2002, the net exports of fisheries commodities by developing countries (ie deducting their imports from the total value of their exports) increased from USD 4 billion to USD 17.4 billion..$^{39}$

Another respect in which the EEZ has proved invaluable to coastal States, particularly those of the developing world, is in the effort made under the Convention to redistribute fisheries resources. ${ }^{40}$ The redistribution was intended largely to be from developed, distancefishing nations to developing coastal States off whose coasts the former used to carry out largescale fishing. As observed by Wijkman in 1982, a total of about USD 1.2 billion would be redistributed to coastal States as fisheries resources under UNCLOS. ${ }^{41}$

Coastal States are accordingly in a position to make the best use of fisheries in that area of the sea, not only by exploiting them but also by conserving and managing them to their own economic advantage. A coastal State with a robust fisheries management policy can therefore conserve, manage and exploit the fisheries resources of its EEZ and maximise the economic benefits therefrom. It is for these reasons that ' $[t]$ he EEZ regime was seen as one of the vehicles in the 1982 Convention for achieving a new international economic order that would redress the economic balance in the interest of developing states'. ${ }^{42}$

\subsection{The Concept of 'Allowable Catch'}

As shown above, the concept of the EEZ under the UNCLOS has afforded developing coastal States the legal backing to exclude the distance-fishing fleets of the developed nations from exploiting fisheries resources in waters adjacent to their territorial seas. They are now in a position to conserve, manage and exploit the fisheries of the EEZ in manners suitable to their economic interests.

However, with this right of exclusive fishing in the EEZ comes the responsibility of ensuring that the fisheries resources of that zone are optimally exploited by the coastal nation exercising that right of exclusivity. UNCLOS enjoins coastal States to promote the objective of optimum utilisation of the living resources of the EEZ. ${ }^{43}$ Since some nations (especially developing ones) lack the financial resources and technological capabilities to engage in the magnitude of deep-sea fishing carried out by the developed, distant-water fishing States, the possibility exists that they may not optimally exploit the fisheries resources of their EEZs, resulting in resource under-utilisation. It is for this reason that UNCLOS has provided for the concept of 'allowable catch'. Under Article 61 of the Convention, each coastal State shall determine the allowable catch of the living resources in their EEZ. Allowable catch refers to the quantities of various species of the living resources of the EEZ a coastal State has

38 Harris (n 16) 475 para 8.

39 Håkan Eggert and Mads Graeker, 'Effects of Global Fisheries on Developing Countries: Possibilities for Income and Threat of Depletion' (2009) Environment for Development 1.

40 Lawrence Juba, 'World Marine Fish Catch in the Age of Exclusive Economic Zones and Exclusive Fisheries Zones' (1991) 22 Ocean Development and International Law 1; Giulio Pontecorvo, 'The Enclosure of the Marine Commons: Adjustment and Redistribution in World Fisheries' (1988) 12 Marine Policy 361.

41 PM Wijkman, 'UNCLOS and the Redistribution of Ocean Wealth' (1982) 16 Journal of World Trade Law 31.

42 Harris (n 16) 475.

43 UNCLOS (n 8) art 62. 
considered appropriate for exploitation without endangering the living resources of the zone by over-exploitation.

Having determined its allowable catch, the coastal State shall then determine its capacity to harvest the living resources of the zone. ${ }^{44}$ Where the coastal State does not have the capacity to harvest the entire allowable catch, it shall, through agreements or other arrangements, give other States access to the surplus of the allowable catch. ${ }^{45}$ These provisions of the Convention are intended to address the problem of possible under-utilisation of the living resources of the EEZ, especially fish stocks. In this way, the coastal State still earns income from licensing fees paid by other States for fishing access.

These provisions, allowing other States to enter and harvest the surplus of a coastal State's allowable catch, were intended to address the problem of possible under-utilisation of fisheries resources, however they pose yet another problem. This problem is the tendency for such other States to over-exploit the fishery resources beyond the surplus of the allowable catch or exploit, in the process, fish species that are not within the allowable catch, thus reducing their populations below the maximum sustainable yield. For the purpose of enhancing and stabilising fishing rights, UNCLOS III anticipated this possibility and included provisions in UNCLOS that encourage States to adopt laws and regulations that stipulate terms and conditions with which the other States parties must comply when harvesting the surplus of an allowable catch. ${ }^{46}$ Such laws and regulations should relate, inter alia, to the various measures contained in Article 62(4) of the Convention, ${ }^{47}$ intended to prevent abuse in harvesting the surplus of the allowable catch.

\subsection{Management of Migratory/Straddling Fish Species}

Fish recognise and respect no Convention maritime boundaries. ${ }^{48}$ In fact, some species ${ }^{49}$ move inconveniently across maritime boundaries. ${ }^{50}$ Such species live different stages of their lifecycle in different marine habitats. By their nature, such species may grow in one marine

4 UNCLOS (n 8) art 62(2).

45 ibid.

46 ibid.

47 Such measures include the licensing of fishermen, fishing vessels and equipment, including: payment of fees and other forms of remuneration, which, in the case of developing coastal States, may consist of adequate compensation in the fields of financing, equipment and technology relating to the fishing industry; determining the species which may be caught and fixing quotas of catch, whether in relation to particular stocks or groups of stocks or catch per vessel over a period of time or to the catch by nationals of any State during a specified period; regulating seasons and areas of fishing, the types, sizes and amount of gear, and the types, sizes and number of fishing vessels that may be used; fixing the age and size of fish and other species that may be caught; specifying information required of fishing vessels, including catch and effort statistics and vessel position reports; requiring, under the authorisation and control of the coastal State, the conduct of specified fisheries research programmes and regulating the conduct of such research, including the sampling of catches, disposition of samples and reporting of associated scientific data; the placing of observers or trainees on board such vessels by the coastal State; the landing of all or any part of the catch by such vessels in the ports of the coastal State; terms and conditions relating to joint ventures or other cooperative arrangements; requirements for the training of personnel and the transfer of fisheries technology, including enhancement of the coastal State's capability of undertaking fisheries research; enforcement procedures. Wijkman (n 41) 27.

49 For a list of highly migratory fish species see UNCLOS (n 8) annex 1.

50 Lawrence Juba, 'The Exclusive Economic Zone Management' (1987) 18 Ocean Development and International Law 305. 


\section{Enhanced Fishing Rights under the United Nations Convention on the Law of the Sea, 1982: The Challenges Confronting Developing Countries 153}

habitat and, when mature and harvestable, migrate to another. Such migration may be from one EEZ to another or from an EEZ to the high seas, where they become amenable to exploitation by all States in consonance with the freedom of fishing in the high seas. The migratory nature of such species tends to negate the Convention idea that coastal States should conserve, manage and exploit the living resources of their EEZ to the exclusion of other States. The pre-UNCLOS era left the issue of migratory fish species and their management unaddressed.

This lacuna was envisioned during UNCLOS III. UNCLOS, therefore, enjoined States to implement measures for the effective management of migratory fish. It laid the foundation upon which States are to build for the purpose of developing arrangements for the management of migratory fish stocks. Under the Convention, three migratory fish categories are identified, depending on the extent and direction of migration. These are highly migratory species ${ }^{51}$ anadromous stocks ${ }^{52}$ and catadromous stocks. ${ }^{53}$ Highly migratory species are fish species that regularly migrate long distances across international waters. ${ }^{54}$ Anadromous stocks are those that migrate from saltwater habitats to freshwater habitats or those that migrate shoreward from the sea, ${ }^{55}$ while catadromous stocks refer to fish stocks that migrate seaward or from freshwater to saltwater habitats. ${ }^{56}$

Since catadromous stocks migrate seawards, the possibility exists that they might migrate from the EEZ of the State of origin to that of another State. If there were no regulations, such stocks having been conserved, managed and maintained by the State of origin will end up being harvested by the other State. UNCLOS envisaged and took measures to deal with such a situation. Where such species migrate in this way, whether as juvenile or maturing fish, the management, including harvesting, of such fish shall be regulated by agreement between the State of origin and the other State concerned, taking into account, however, the responsibility of the State of origin in the maintenance of the species. ${ }^{57}$ In respect of migratory fish stocks, UNCLOS therefore set up a platform for States to ensure, through agreement, effective management of migratory species to their mutual economic benefit. This is something which, before the Convention, was left to the unrestrained whims of States.

Despite the efforts of UNCLOS to encourage States to reach agreements on the modalities of managing migratory fish species, conflicts still arose regarding the exploitation of those trans-boundary fish stocks. It was in response to such conflicts that the UN convened the United Nations Conference on Straddling Fish Stocks and Highly Migratory Fish Stocks in $1995 .{ }^{58}$ The Conference adopted the United Nations Fish Stocks Agreement (UNFSA). ${ }^{59}$

51 UNCLOS (n 8) art 64.

52 UNCLOS (n 8) art 66.

53 UNCLOS (n 8) art 67.

54 RP Khodorevskaya, GI Ruban and DS Pavlov, Behaviour, Migrations, Distribution, and Stocks of Sturgeons in the Volgan-Caspian Basin (Books on Demand GmbH 2009).

55 ibid.

56 ibid.

57 UNCLOS (n 8) art 67(3).

58 The Conference was held in New York from 24 July to 4 August 1995.

59 Agreement for the Implementation of the Provisions of the United Nations Convention on the Law of the Sea of 10 December 1982 Relating to the Conservation and Management of the Straddling Fish Stocks and Highly Migratory Fish Stocks (UNFSA) (adopted 4 August 1995, entered into force 11 December 2001) 2167 UNTS 3; 78 States and entities have ratified the Agreement to date. 
The Agreement, according to Nandan, is a strong and far-reaching instrument and by far the most comprehensive agreement relating to the conservation and management of fish stocks. ${ }^{60}$

The UNFSA requires the management of straddling/highly migratory fish stocks on a sub-region by sub-region basis through Regional Fisheries Management Organisations (RFMOs). ${ }^{61}$ Following the UNFSA, various RFMOs have been established on sub-regional basis, ${ }^{62}$ with the objective, among others, to 'agree, as appropriate, on participatory rights [of States Parties] such as allocations of allowable catch or levels of fishing effort.' ${ }^{63}$ Although existing RFMOs have been shown to have their imperfections, ${ }^{64}$ they have succeeded in curbing the problem of incessant fisheries crises, especially those pertaining to allowable catch, in sub-regions where they have been established. ${ }^{65}$

\subsection{Protection and Preservation of the Marine Environment}

For sea fisheries to be properly conserved, managed and profitably exploited, it is necessary for the marine environment to be protected and preserved, since adverse changes in fish habitat are bound to alter fish populations. Unless the marine environment is protected, whatever effort is made by States, whether through the UN, regional or sub-regional arrangements, to enhance the development of fisheries resources and protect fishing rights, would be effectively discounted by pollution of the marine environment.

As another way of stabilising and enhancing fishing rights under the UNCLOS, States dedicated the whole of Part XII of the Convention to the protection and preservation of the marine environment. The provisions are intended to enable States to take measures to prevent, reduce and control pollution of the marine environment. Under the Convention, 'pollution of the marine environment' is defined as:

The introduction by man, directly or indirectly, of substances or energy into the marine environment, including estuaries, which results or is likely to result in such deleterious effects as harm to living resources and marine life, hazards to human health, hindrance to marine activities, including fishing and other legitimate uses of the sea, impairment of quality for use of sea water and reduction of amenities. ${ }^{66}$

Under UNCLOS, States have a general obligation to protect and preserve the marine environment against pollution. ${ }^{67}$ They are required to take measures individually or jointly to

60 Statement of Satya Nandan, Secretary-General of the International Seabed Authority, 'Agenda Item 49; Oceans and the Law of the Sea' $\left(59^{\text {th }}\right.$ Session of the General Assembly of the United Nations, 17 November 2004) 5 .

61 UNFSA (n 59) arts 7, 8.

62 These include: the South East Atlantic Fisheries Organisation (SEAFO); the Western and Central Pacific Fisheries Commission (WCPFC), otherwise known as the Tuna Commission; the Inter-American Tropical Tuna Commission (IATTC); the North-East Atlantic Fisheries Commission (NEAFC); the Convention on the Conservation of Antarctic Marine Living Resources (CCAMLR) (adopted 20 May 1980, entered into force 7 April 1982) 1329 UNTS 47.

63 UNFSA (n 59) art 10(b).

64 For a detailed study of the problems associated with RFMOs, see Anthony Cox, 'Quota Allocation in International Fisheries' (OECD Food, Agriculture and Fisheries Papers No 22, 2009) $<$ dx.doi.org/10.1787/218520326143> accessed 29 November 2019.

65 ibid.

66 UNCLOS (n 8) art 1(4).

67 UNCLOS (n 8) art 192. 


\section{Enhanced Fishing Rights under the United Nations Convention on the Law of the Sea, 1982: The Challenges Confronting Developing Countries 155}

prevent, reduce, or control pollution of the marine environment from land-based sources, ${ }^{68}$ the atmosphere, ${ }^{69}$ through dumping,$^{70}$ by vessels plying the seas,${ }^{71}$ from installations and devices used in exploration or exploitation of the natural resources of the seabed and subsoil within national jurisdiction ${ }^{72}$ and from activities in the area. ${ }^{73}$

States must also co-operate and, directly or through international organisations, carry out studies, research and programmes for the prevention, reduction and control of pollution in the marine environment. ${ }^{74}$ States act in concert in this regard, mainly through the International Maritime Organisation (IMO) ${ }^{75}$ and the United Nations Environmental Programme (UNEP) ${ }^{76}$ The IMO, within its environmental mandate, has developed and adopted a range of international instruments to address marine pollution arising from international shipping. ${ }^{77}$ Its efforts in this regard have led to reduced marine pollution arising from the activities of vessels plying the high seas.

Recognising the obvious lack of resources and capacity among developing nations to adequately confront the problem of marine pollution, the Convention requires that such countries be granted preference by international organisations in the allocation of appropriate funds and technical assistance and the utilisation of the specialised services of international organisations. ${ }^{78}$ Thus, where resources available to international organisations for assisting States in marine pollution prevention are limited, preference is to be given to developing countries in the allocation of such resources. UNCLOS also contains copious provisions relating to enforcement of the Convention and the local maritime laws and regulations of States for the purpose of ensuring compliance by persons carrying out activities that constitute

\footnotetext{
68 UNCLOS (n 8) art 207.

69 UNCLOS (n 8) art 212.

70 UNCLOS (n 8) art 210.

71 UNCLOS (n 8) art 211.

72 UNCLOS (n 8) art 214.

73 UNCLOS (n 8) art 215; the 'area' under art 1(1) UNCLOS is used to refer to the seabed, ocean floor and subsoil beyond the outer edge of the continental break or margin of a coastal State.

74 UNCLOS (n 8) arts 200-202.

75 The IMO is a UN specialised agency with a mandate to promote, secure and ensure environmentally sound, efficient and sustainable shipping.

76 UNEP is an agency of the UN that coordinates UN environmental activities and assists developing countries in implementing environmentally sound practices.

77 Such instruments include the International Convention for the Prevention of Pollution from Ships (adopted 2 November 1973, entered into force 2 October 1983) 1340 UNTS 184; International Convention Relating to Intervention on the High Seas in Cases of Oil Pollution Casualties (adopted 29 November 1969, entered into force 6 May 1975) 970 UNTS 211; International Convention on Oil Pollution Preparedness, Response and Cooperation (adopted 30 November 1990, entered into force 13 May 1995) 1891 UNTS 51; International Convention on Civil Liability for Oil Pollution Damage (adopted 29 November 1969, entered into force 19 June 1975) 973 UNTS 3; Convention on Prevention of Pollution by Dumping of Wastes and other Matter (adopted 29 December 1972, entered into force 30 August 1975) 1046 UNTS 120; International Convention on the Control of Harmful Anti-fouling Systems on Ships (adopted 5 October 2001, entered into force 17 September 2008) IMO Doc AFS/CONF/26; the International Convention for the Control and Management of Ships' Ballast Water and Sediments (adopted 13 February 2004, entered into force 8 September 2017) IMO Doc BWM/CONF/36.

78 UNCLOS (n 8) art 203.
} 
potential threats to the marine environment. Flag States, ${ }^{79}$ port States ${ }^{80}$ and all coastal States ${ }^{81}$ are required to ensure the enforcement of maritime laws and regulations over vessels in order to prevent pollution of the marine environment.

\section{The Challenges Confronting Developing Countries}

The view is held by various scholars that UNCLOS holds many economic prospects for developing countries. ${ }^{82}$ It is their thinking that the Convention brought with it the seed of a new international economic order under which developing countries stand to reap many economic benefits. One of the areas in which they expected that developing countries would have an advantage is in the exploitation of sea fisheries. As discussed above, the EEZ revolutionised fishing rights globally, vesting the exclusive right to conserve, manage and exploit the living resources of the zone in coastal States for their own economic benefit. The EEZ proves beneficial to developing countries which, before the Convention, watched the distance-fishing fleets of the developed countries exploit the fisheries of that zone as part of the high seas. ${ }^{83}$ Today, developing countries can, through well thought-out fisheries laws, regulations and policies, maximise the benefits of their fisheries resources within the expansive EEZ. ${ }^{84}$

A contrario, over three decades since the adoption of the UNCLOS, most developing countries have yet to develop effective fishing policies that cater to the needs of management, conservation and optimal utilisation of fisheries resources. Although the problem of unsatisfactory fisheries management is a global one ${ }^{85}$ the situation is worse among developing

79 UNCLOS (n 8) art 217.

80 UNCLOS (n 8) art 218.

81 UNCLOS (n 8) art 220.

82 Harris (n 16) 475 para 8; Essien (n 1) 108-116; Ken Roberts, 'Legal and Institutional Aspects of Fisheries in West Africa' (1998) 10 International Journal of African Law 88; see generally UNCLOS (n 8) preamble, which aspires that the Convention should 'contribute to the realization of a just and equitable international economic order which takes into account the interests and needs of mankind as a whole, and in particular, the special interests and needs of developing countries, whether coastal or land locked.' (emphasis added).

83 Overseas Development Institute (ODI), 'Fisheries and the Third World' (Briefing Paper 2, June 1984).

84 In fact, during the period 1989-2002, the net exports of fisheries commodities by developing countries (ie deducting their imports from the total value of their exports) increased from USD 4 billion to USD 17.4 billion. This was greater than the net exports of other agricultural commodities such as rice, cocoa, tobacco, and tea; see research work commissioned by Environment and Trade in a World of Interdependence (ENTWINED) and Foundation for Strategic Environmental Research, Eggert and Graeker (n 39) 1.

85 For example, in the last decade, in the North Atlantic Region, commercial fish populations of species like cod, hake, haddock and flounder have fallen by as much as $95 \%$, prompting calls for urgent measures. Despite also the high level of awareness and development among the developed countries, marine area protection and conservation has not been impressive across the world. In fact, it is estimated by UNEP that less than one percent of the world's oceans are currently Marine Protected Areas (MPAs) and according to the Food and Agricultural Organisation (FAO), over 70\% of the world's fish species are either fully exploited or depleted; see United Nations Environment Programme (UNEP), 'Overfishing: A Threat to Marine Biodiversity' <unis.unvienna.org/documents/unis/ten_stories/09fisheries.pdf> accessed 29 November 2019; according to Eggert and Graeker, more than $20 \%$ of fish stocks have crashed across the world, $40 \%$ are overexploited and the remaining $35 \%$ are fully exploited, a trend that is bound to threaten ecosystems and lead to poor yield and low income; see Eggert and Graeker (n 39) 2; D Pauly and others, 'Towards Sustainability in World Fisheries' (2002) 418 Nature 689; EB Barber and others, 'Impacts of Biodiversity Loss on Ocean Ecosystem Services' (2006) 314 Science 789, 789-90. 


\section{Enhanced Fishing Rights under the United Nations Convention on the Law of the Sea, 1982: The Challenges Confronting Developing Countries 157}

countries. ${ }^{86}$ For these countries (especially those in Africa), it has been either a case of overfishing without any plan for yield sustainability, or sub-optimal utilisation of fisheries as a result of lack of capacity resulting in low fishing effort.

Whether as overfishing or fisheries under-utilisation, poor fisheries management has serious adverse economic consequences for developing countries. The most obvious economic impact of poor fisheries management on developing countries is direct loss of the value of the catches that could be taken by developing coastal States if their fisheries were properly managed. Aside from the loss to GNP, 'actual revenue can accrue to the coastal state in the form of landing fees, licence fees, taxes and other levies which are payable by legal fishing operators' ${ }^{87}$ Aside from its direct macro-economic impacts on developing economies, there are also indirect and more subtle impacts on the global economy. These include the impacts resulting from loss of income and employment in other industries and activities in the supply chain, both upstream and downstream. ${ }^{8}$

A major cause of poor fisheries management among developing countries is the absence of clear fisheries policies and the necessary political will to enforce laws and regulations. Since most developing countries are characterised by a low governance level, fisheries policies are not formulated with the importance they deserve, especially in countries where there are more profitable resources. As a result, regulations are incomprehensive and enforcement perfunctory. Although some have legislation providing copious regulations for fishing activities in their waters, most developing countries are most lackadaisical about the enforcement of regulations. Both artisanal and industrial fishing are, therefore, largely unregulated. As Eggert and Greaker have observed, 'management is often de facto open access, where vessels with or without permission to fish land as much as they can catch due to limited monitoring and enforcement activities' ${ }^{89}$ Monitoring, ${ }^{90}$ contro $^{91}$ and surveillance ${ }^{92}$ (MSC), which are imperatives for effective fisheries management, are either non-existent or ineffective where they do exist. The consequence is thriving illegal, unreported and unregulated (IUU) fishing in developing countries' waters. It is estimated, for example, that nineteen percent of current landed value in sub-Saharan Africa is being caught by IUU fishing. ${ }^{93}$ The elimination of IUU fishing among developing countries will correspond to improved foreign exchange earnings for the countries concerned where the IUU fish are export fish ${ }^{94}$ and contribute to food security of artisanal fishermen where the IUU fish are locally consumed fish. ${ }^{95}$

Due to overfishing, which is a consequence of poor fisheries management, South Africa, for example, is faced with a dire case of overfishing, so much so that the country is left

86 ibid.

87 Marine Resources Assessment Group (MRAG), 'Review of Impacts of Illegal, Unreported and Unregulated Fishing on Developing Countries' (Synthesis Report, June 2005) 5.

88 ibid.

89 Eggert and Graeker (n 39) 1.

90 'Monitoring' is the continual measurement of fishing effort, characteristics and catches.

91 'Control' refers to the entire legal framework within which fisheries resources may be exploited.

92 'Surveillance' embraces all measures required to ensure compliance with the established legal framework.

93 MRAG (n 87) 11.

94 In Seychelles, for example, IUU fishing involves mainly export tuna; ibid.

95 In West Africa, IUU fishing is predominantly in respect of inshore shrimp and demersal fish consumed locally; ibid. 
with less than five percent of its original fish populations. ${ }^{96}$ In South Africa, due to poor conservation and management, fisheries have been so over-exploited that it has become difficult to sustain yields. Such fish stock depletion does not only pose a danger to the ecosystem, but also 'poses a major threat to the food supply of millions of people' ${ }^{97}$ A study of illegal fishing in ten developing countries, ${ }^{98}$ between 2003 and 2004, showed that Guinea alone lost over USD 100 million to illegal and pirate fishing within that period. ${ }^{99}$

At the other extreme are developing countries that suffer sub-optimal utilisation of their fisheries resources. Ghana and Nigeria are examples of this. Ghana has rich fisheries, but under-utilisation has necessitated fish importation. With an estimated annual fish requirement of 880,000 tonnes, Ghana's production stands at an average of 420,000 tonnes leaving a deficit of 460,000 tonnes which is compensated for through fish imports. ${ }^{100}$ In the case of Nigeria, despite its high potential for fish production, it still depends on fish imports to meet its domestic fish demands. ${ }^{101}$ It is generally believed that if Nigeria's fisheries resources are 'rationally managed and exploited, the country can attain sufficiency in fish production'. ${ }^{102}$ The result of fisheries under-utilisation has therefore been the legal or illegal harvesting of the surplus catch by the fishing vessels of the developed countries. It is in fact estimated that 5060 percent of the world's catch is made by European fishermen and that a large part of that is from waters under the jurisdiction of developing countries. ${ }^{103}$

For the prevention of the under-utilisation of fisheries resources owing to low fishing efforts, Article 61 of UNCLOS requires coastal States to determine the total allowable catch of the living resources of their EEZ, and under Article 62(2) they are then to determine their catch capabilities. The surplus is to be made available to other States for exploitation through agreements or other arrangements. ${ }^{104}$ This provision of the UNCLOS is, as earlier pointed out, intended to prevent fisheries resource under-exploitation. However, the determination of both allowable catch and a country's catch capability requires the availability of accurate marine biodiversity data and information which are not readily available in developing countries. The result is an obvious inability of developing countries to accurately determine their total allowable catch and their harvesting capacities. With the paucity of such data and information, it is difficult to determine and allocate surplus to States with the necessary capability and fishing effort. Developing countries are, therefore, deprived of revenues that

96 Environment South Africa, 'Methods to Help South Africa's Overfishing Problem' (17 June 2016) <environment.co.za/wildlife-endangered-species/methods-to-help-south-africas-overfishing-problem.html> accessed 29 November 2019.

97 ibid.

98 Guinea, Somalia, Angola, Mozambique, Papua New Guinea, Sierra Leone, Liberia, Seychelles, Kenya and Namibia.

99 MRAG (n 87) 6.

100 Theodore Kwadjosse, 'The Law of The Sea: Impacts on the Conservation and Management of Fisheries Resources of Developing Coastal States - The Ghana Case Study' (2009) $<$ un.org/Depts/los/nippon/unnff_programme_home/fellows_pages/fellows_papers/kwadjosse_0809_gha na.pdf> accessed 14 December 20193.

${ }^{101}$ FD Sikoki, 'Fishes in Nigerian Waters: No Place to Hide' (Inaugural Lecture Series No 100, University of Port Harcourt, 31 January 2013) 43.

102 ibid 13.

${ }^{103}$ Publications Office of the European Union, 'Fisheries: Fisheries and Poverty Reduction' (2002) <europa.eu/legislation_summaries/defelopment/sectoral_development_policies/r12512_en.htm> accessed 29 November 2019.

${ }^{104}$ UNCLOS (n 8) art 62(2). 


\section{Enhanced Fishing Rights under the United Nations Convention on the Law of the Sea, 1982: The Challenges Confronting Developing Countries 159}

ought to accrue from licensing fees, vessel registration fees, and landing fees. Even where allocations were possible and licences were granted to foreign fishers, bribery and corruption proved major obstacles to realising targets as vessel licensing was irregular, catches were not being reported and permits were granted to fishers who did not meet the required criteria. ${ }^{105}$

There has also been a failure, or lack of co-operation, between neighbouring developing coastal countries on maritime surveillance. With limited surveillance capabilities over their expansive waters, cooperation becomes necessary but is usually lacking. With the limited solo efforts of these States at surveillance, it has proved difficult to eliminate IUU fishing. ${ }^{106}$

Modern fisheries management requires cooperation agreements among States on a regional or sub-regional basis for the effective management of migratory/straddling fish stocks. It is for this reason that UNCLOS enjoins States in the same region to cooperate directly or through appropriate international organisations with a view to ensuring conservation and promoting the objective of optimum utilisation of such species throughout the region, both within and beyond the EEZ. ${ }^{107}$ This is strengthened by Article 8 of the UNFSA which imposes a duty to cooperate through RFMOs, by providing that only members of RFMOs, or non-members which agree to apply the conservation and management measures adopted by RFMOS, can have access to the particular fishery. This requires not only the establishment of RFMOs among developing countries in the same region, but also ensuring the effectuality of such organisations. It has been estimated that highly migratory/straddling fish species account for as much as one-third of world's marine capture fish harvests. ${ }^{108}$ This illustrates the economic importance of these fish species. Although several RFMOs or similar bodies have been established in various developing regions of the world for the management of trans-boundary fish stocks both within the EEZ and beyond, ${ }^{109}$ many other regions have yet to establish them. In most cases, cultural, linguistic, geographical and historical differences between countries in the same region militate against the establishment and efficient operation of RFMOs. In West Africa, for example, these factors have made difficult the establishment and successful operation of RFMOs. ${ }^{110}$

RFMOs play the significant role of gathering data on fisheries resources of the particular fisheries concerned and allocating allowable catch or fishing effort among members. ${ }^{111}$ In regions where there are no RFMOs, or where they exist but are ineffective, it is difficult to gather data and impossible to devise an acceptable allocation system that ensures yield sustainability.

In some regions of Africa, certain maritime boundaries are still unclear, making the operation of RFMOs difficult. For instance, despite UNCLOS, Angola and Namibia have yet

\footnotetext{
${ }^{105}$ Eggert and Graeker (n 39) 11.

106 ibid 13.

107 UNCLOS (n 8) arts 63(1), 118.

108 Gordon Munro, Annick Van Houtte and Rolf William, 'The Conservation and Management of Shared Fish Stocks: Legal and Economic Aspects' (FAO Fisheries Technical Paper No 465, 2004) $<$ fao.org/3/y5438e/y5438e00.htm> accessed 29 November 2019, 7.

${ }^{109}$ In Africa, for example, there have been the Commission for Eastern Central Atlantic Fisheries created in 1967; the Ministerial Conference on Fisheries Cooperation Among States Bordering the Atlantic Ocean created in 1989 and the Sub-Regional Fisheries Commission created on 29 March 1985.

110 Roberts (n 82) 10.

${ }^{111}$ UNFSA (n 59) art 10(b); Cox (n 64) 11.
} 
to finalise their EEZ and continental shelf boundaries, ${ }^{112}$ and Angola and South Africa have yet to establish their maritime boundaries. ${ }^{113}$ Aside from uncertainties over boundaries, some developing countries still, in practice, make extra-Conventional claims of expansive territorial seas and sometimes undeclared breadths of EEZ. Benin and Sierra Leone, for example, maintain territorial seas of 200 miles; ${ }^{114}$ Nigeria claims one of over 12 miles; ${ }^{115}$ while Cameroon asserts a claim of a 50-mile territorial sea without any declared EEZ. ${ }^{116}$ This in many ways hinders the use of MCS measures to protect fisheries jurisdiction and manage fisheries in those regions. Even where they exist among developing countries, most RFMOs have generally been deemed ineffective as regards their abilities to ensure the conservation of fish stocks. ${ }^{117}$

Equally militating against the maximisation of the benefits of enhanced fishing rights under UNCLOS in developing countries is the absence of subsidies for the fishing industry. In the developed countries of Japan, Russia and China, as well as in Eastern and Western Europe, subsidies have long been provided for the fishing industries, aimed at developing distant water fleets for the global catch race. ${ }^{118}$ According to Sumaila and Pauly, in conservative terms, about USD 30-34 billion worth of subsidies are provided by governments annually to the fishing industry. ${ }^{119}$ This, unfortunately, is a rarity in developing countries.

Subsidies can be internal or external. They are internal when they are provided by the domestic government and external when they are made available by foreign governments or organisations. Through subsidies, industrial fishing is encouraged as fishers are provided with the necessary capital needed to increase fishing effort and therefore also increase harvests.

Due to poverty, corruption and oftentimes misplaced priorities, such subsidies are hardly available in most developing countries. This has perpetuated low fishing efforts in those countries, resulting in fisheries under-utilisation. Good subsidies do not only promote growth in fishing effort (where it is considered economically advisable), but also attend to the needs of stock conservation and management through improvement of fisheries monitoring, surveillance and control. ${ }^{120}$

\section{Recommendations}

Governments of developing coastal countries must begin to prioritise the fisheries resources of their EEZs as a national revenue source. The development of the concept of the EEZ was championed by developing States in response to the massive exploitation of their sea fisheries by the distant water fishing fleets of industrialised States. Since the creation of the exclusive economic zone, however, most developing countries have yet to efficiently exploit the huge fisheries resources of the EEZ.

As inefficiency in the operations of public corporations is a common feature of developing countries, the private sector should be largely involved in the management and

\footnotetext{
112 Roberts (n 82) 120.

113 ibid.

114 ibid.

115 ibid.

116 ibid.

117 Cullis-Suzuki and Pauly (n 5) 1036-1042; Roberts (n 82) 116.

118 Eggert and Graeker (n 39) 15.

119 UR Sumaila and D Pauly (eds), 'Catching More Baits: A Bottom-Up Re-estimation of Global Fisheries Subsidies' (2006) 14(6) Fisheries Centre Research Reports 1.

120 Eggert and Graeker (n 39) 16.
} 


\section{Enhanced Fishing Rights under the United Nations Convention on the Law of the Sea, 1982: The Challenges Confronting Developing Countries 161}

exploitation of sea fisheries in developing countries. These countries stand to earn huge revenues from licensing and other fees paid by industrial fishers. Aside from revenues, with the private sector largely involved, a value chain will develop which will in turn create muchneeded employment opportunities in these countries. All these will, in the long run, have expansionary effects on developing economies. Governments of developing countries must begin to see sea fisheries as potential contributors to their national economy and begin to diversify their economies in that direction.

No effort at maximising the benefits of EEZ fisheries of developing countries will yield appreciable results without a virile and robust system of enforcing maritime laws and regulations. These countries are not in deficit regarding maritime laws and regulations, but the enforcement thereof is a problem. The consequence has been open-access fishing in the waters of these countries by fishermen from all over the world. Governments of developing States must therefore muster the political will to enforce their maritime laws and regulations irrespective of how powerful the offenders might be. Relevant law-enforcement agencies should be adequately equipped to protect and secure waters in those countries from IUU fishing. Vessels and aircraft equipped with radars, electronic emission scanning equipment and other modern surveillance gadgets should be made available for the onerous task of modern maritime surveillance.

In addition to the governments of developing countries securing and protecting their maritime zones, they must also increase the fishing efforts of their own countries. Excluding illegal fishers without themselves doing enough fishing will only result in the under-utilisation of fisheries resources, which is asynchronous with the fisheries management prescriptions of UNCLOS. ${ }^{121}$ For third world countries affected by the sub-optimal utilisation of fisheries, fishing effort must be increased. To achieve this, both internal and external subsidies should be introduced to encourage industrial fishing. Argentina offers a good example of a developing country that increased fishing effort over a short period of time using mainly external subsidies. Under an agreement entered into in 1994, the EU gave subsidies to Argentina for the establishment of joint ventures with local firms in order that EU member States' vessels could have access to Argentina's EEZ. Under the agreement, the EU gave subsidies to Argentina to an estimated tune of USD 230 million. ${ }^{122}$ As a result of that arrangement, between 1985 and 1995, Argentina's fishing effort increased, with the aggregate motor power of its fishing fleet rising from 25,000 horsepower (hp) in 1990 to almost 200,000 hp in $1995 .{ }^{123}$ Correspondingly, the country's fish export grew by almost 500 percent over the same period. ${ }^{124}$ The Argentinian experience can be replicated in other third world countries where fishing effort is low.

In the case of developing countries plagued by overfishing, policies must urgently be formulated, and legislation enacted, that are geared towards reducing exploitation and returning fish yields to sustainable levels. Such policies and legislation must seek to curb IUU

\footnotetext{
${ }^{121}$ A major policy of the Convention is fisheries resource conservation and management aimed at ensuring optimal resource exploitation and preventing resource under-utilisation. This is the very purpose of such Convention concepts as allowable catch, harvesting capacity and surplus allocation under Part $\mathrm{V}$ of the Convention; see UNCLOS (n 8) Part V.

${ }_{122}$ Eggert and Graeker (n 39) 1.

123 ibid.

124 ibid.
} 
fishing through effective restrictions that allow access only to licensed fishers. Overfishing is, however, not only a consequence of IUU fishing. It is also, in some cases, a result of excess fishing by the coastal State itself. In developing countries where this is the case, law and policy should be aimed at reducing fishing efforts. This can be achieved by reducing the aggregate motor power of the coastal State's fishing fleet. ${ }^{125}$ Such reduction could be for a definite or indefinite period. In this way, yield sustainability could be ensured over time.

Most developing countries have no clear-cut fisheries management policies. Resultantly, there are usually no objectives, nor mechanisms, for decision-making and no plans for ensuring implementation and compliance. Yet, these are essential elements that constitute any workable fisheries management policy, without which management is useless. Alabsi and Komatsu have pointed out thus:

Fisheries management usually must have a policy framework which sets objectives to achieve and mechanisms to follow in decision-making. Next, it must have a suite of laws and regulations to control stakeholders' behavior. Finally, it must have an enforcement power to ensure compliance and implementation of these rules in practice. How appropriate these tools are to a specific fishery, will determine the type and success of the resulted management. ${ }^{126}$

This makes it imperative for governments of third world countries to articulate and develop fisheries policies that set out clear objectives, establish legal and regulatory frameworks and set up implementation mechanisms. In this way, performance can always be evaluated and relevant institutions strengthened. Leaving fisheries to ad hoc management and knee-jerk reactions in developing countries will perpetuate fisheries over-exploitation or underutilisation, both of which are features of poor fisheries management.

Although UNCLOS enjoins states to establish RFMOs in their various regions, ${ }^{127}$ developing countries have yet to take advantage of such organisations. RFMOs, inter alia, ensure effective collective management of migratory/straddling fish species by coastal countries in the region. They allocate fishing quotas to members and thus ensure optimal resource utilisation of migratory fish and reduce conflicts over fishing rights among coastal States in the region. Among developing countries where such organisations have yet to be established, migratory fish are lost as they migrate to the high seas, where they are harvested by distant-water fishers from developed countries in line with the doctrine of high seas freedom. There is, therefore, need for RFMOs to be established in various regions and subregions of Africa, Asia and Latin America, for the avoidance of resource loss and conflicts over fishing rights.

\section{Conclusion}

The UNCLOS is reputed to have greatly enhanced and stabilised fishing rights and thus minimised the international fisheries-related maritime disagreements of the pre-Convention era. With the wider fisheries jurisdictions granted to coastal States under the Convention and

125 This will, however, prove difficult where, as in most developing countries, there are no reliable data on the harvesting capacities of fishing fleets upon which fishing efforts could be determined and upon which policymakers may make decisions.

126 Natheer Alabsi and Teruhisa Komatsu, 'Characterisation of Fisheries Management in Yemen: A Case Study of a Developing Country's Management Regime' (2014) 50 Marine Policy 91.

127 UNCLOS (n 8) art 63. 


\section{Enhanced Fishing Rights under the United Nations Convention on the Law of the Sea, 1982: The Challenges Confronting Developing Countries 163}

considering the economic importance of fish in today's world, it was reasonably expected that coastal States would maximise fishing efforts in their waters, enact laws and regulations and develop national fisheries policies for national economic growth. This has not been the case in most developing countries. The combined factors of inadequate fisheries policy, poverty, corruption, ignorance, poor maritime law enforcement and a characteristic lack of political will to develop fisheries have all contributed to diminishing earnings from sea fisheries in developing countries.

Developing coastal countries must take full advantage of their enlarged fisheries jurisdiction under UNCLOS, not only to meet local fish demand but also to boost foreign exchange earnings. In a globalised world of capitalist economic competition, diversification of national economies has become a survival strategy. The development of fisheries resources (with which most developing coastal States are abundantly blessed) remains one of the best chances in any genuine effort in the diversification of the economies of developing coastal States. 